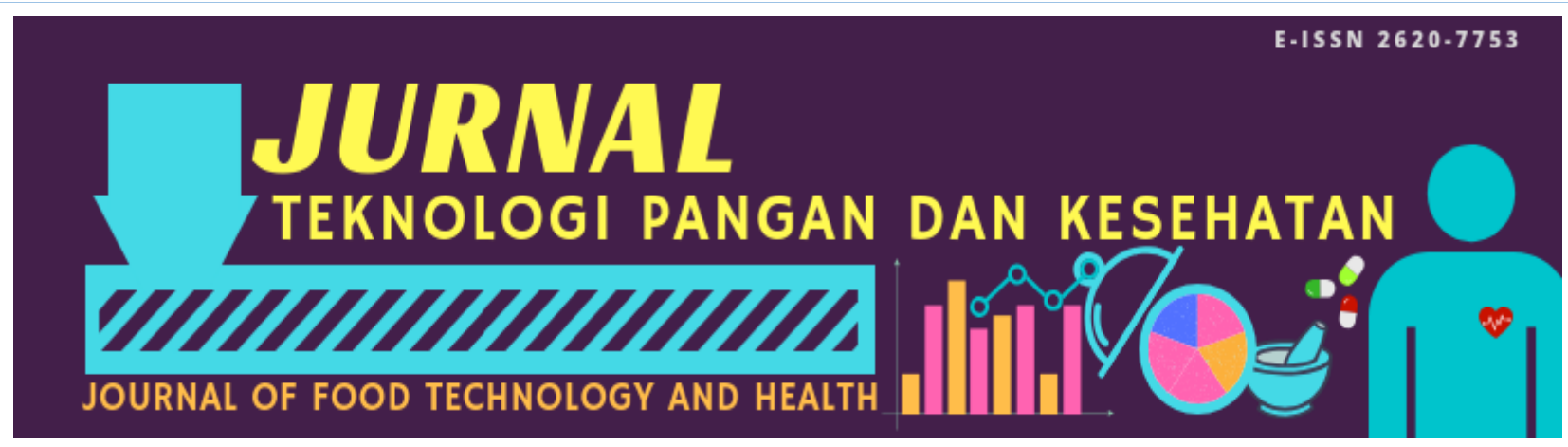

Volume I Nomor I Tahun 2019

Hasil Penelitian

Diterima 2 Jan 2019

Disetujui 28 Mei 2019

\title{
KARAKTERISTIK SENSORIS DAN KANDUNGAN LOGAM BERAT MINUMAN FUNGSIONAL OKRA-JAHE DENGAN BERBAGAI JENIS PEMANIS
}

\author{
Julfi Restu Amelia*, Intan Nurul Azni, Rusi Dwi Oktaviani \\ Universitas Sahid, Jakarta
}

\begin{abstract}
ABSTRAK: Okra merupakan sayuran yang dapat dikonsumsi dalam keadaan segar maupun diolah. Okra dapat dimanfaatkan menjadi minuman kesehatan karena kaya akan zat gizi dan fitokimia yang bermanfaat bagi kesehatan. Minuman okra memiliki nilai sensori yang kurang baik, sehingga perlu adanya bahan tambahan untuk memperbaiki hal tersebut. Bahan tambahan yang dapat digunakan adalah jahe dan pemanis untuk meningkatkan nilai sensori aroma dan rasa. Jahe merupakan tanaman herbal yang memiliki kandungan yang baik bagi kesehatan serta memiliki flavor yang khas. Pemanis yang digunakan dalam penelitian ini adalah daun stevia, madu, sorbitol dan sukrosa. Penelitian ini bertujuan untuk mengkarakterisasi sifat sensori dan kandungan logam berat minuman fungsional okra-jahe dengan penambahan berbagai jenis pemanis. Sifat sensori menggunakan uji hedonik dengan parameter warna, rasa, aroma, dan kekentalan, sedangkan pengujian kimia terhadap kadar logam berat meliputi $\mathrm{Pb}, \mathrm{Cd}, \mathrm{As}, \mathrm{Hg}$, Sn. Perbandingan antara okra:jahe:pemanis adalah 75\%:3\%:22\%. Berdasarkan uji hedonik, untuk parameter warna dan kekentalan minuman okra dengan pemanis sorbitol mendapatkan skor yang tertinggi. Sedangkan pada parameter rasa dan aroma, minuman okra dengan pemanis sukrosa mendapatkan skor yang tertinggi. Hasil analisis kadar logam berat $\mathrm{Pb}, \mathrm{Cd}, \mathrm{As}, \mathrm{Hg}$, dan Sn menunjukkan hasil negatif di semua sampel.
\end{abstract}

Kata Kunci: Jahe, minuman, pemanis, okra

ABSTRACT: Lady's finger is a vegetable that can be consumed fresh or processed. Lady's finger can be used as a functional drink because it is rich in nutrients and phytochemicals that are beneficial to health. Unfortunately this drink has poor sensory performance, so it needs additional ingredients to improve this sensory properties. Additional ingredients include ginger and sweetener to increase the sensory acceptability of aroma and taste. Ginger is an herbal plant that has a bioactive content that is good for health and has a distinctive flavor. The sweeteners used in this study were stevia leaves, honey, sorbitol and sucrose. This study aimed to characterize the sensory properties and heavy metals contet of lady's finger-ginger functional drinks with the addition of various types of sweeteners. Sensory properties were observed using hedonic tests with parameters of color, taste, aroma, and viscosity, while the chemical analysis was focused on the levels of heavy metals including Pb, Cd, $\mathrm{As}, \mathrm{Hg}, \mathrm{Sn}$. The ratio of lady's finger: ginger: sweetener in the formulation were 75: 3: 22. Based on the hedonic test, for color and viscosity of lady's finger drinks with sorbitol sweetener got the highest score. While on the taste and aroma parameters, lady's finger drinks with sucrose sweetener get the highest score. The results of heavy metals on Pb, $\mathrm{Cd}, \mathrm{As}, \mathrm{Hg}$, and Sn showed undetected in all samples.

Keywords: Drink, ginger, lady's finger, sweeteners

\section{PENDAHULUAN}

Tanaman okra (Abelmoschus esculentus) adalah tanaman sayuran yang dapat tumbuh di daerah tropis dan subtropis. Okra dapat dikonsumsi dalam keadaan segar maupun diolah terlebih dahulu dengan cara digoreng dan direbus (Gemede et al., 2015, Azni et al., 2019). Okra dapat diolah menjadi berbagai produk olahan pangan, salah satunya minuman fungsional. Kekurangan dari minuman fungsional okra yaitu masih memiliki nilai sensori yang kurang baik,

*Email korespondensi: fiamel2702@gmail.com 
seperti aroma yang tidak enak dan memiliki penampilan berlendir sehingga perlu adanya bahan tambahan untuk memperbaiki hal tersebut, sehingga perlu adanya bahan tambahan untuk memperbaiki hal tersebut, salah satunya adalah ekstrak jahe untuk menghasilkan minuman fungsional okrajahe. Selain itu untuk meningkatkan nilai sensori dari rasa dan aroma dapat ditambahkan bahan pemanis, seperti stevia, madu, sorbitol dan sukrosa.

Jahe (Zingiber officinale) merupakan kelompok tanaman dari famili Zingiberaceae yang memiliki komponen aktif bernama gingerol. Jahe memiliki 2 komponen yaitu komponen volatil dan nonvolatil. Komponen volatil terdiri dari zingeberene, curcumene, farnesene yang berperan menghasilkan aroma yang khas pada jahe. Komponen nonvolatil yaitu gingerol, shogaol, paradol, dan zingerone berperan dalam menghasilkan rasa pedas di mulut ketika mengonsumsinya. Ekstrak jahe mengandung komponen polifenol yang berperan sebagai antioksidan (Gupta dan Sharma, 2014).

Tanaman Stevia (Stevia rebaudiana) mempunyai tingkat kemanisan 200-300 kali dari pemanis yang berasal dari gula tebu serta memiliki kalori yang rendah, tidak mengganggu rasa minuman sirup, dan tidak bersifat karsinogenik (Ratnani dan Anggraeni, 2005). Senyawa glikosida merupakan senyawa yang terdapat pada daun stevia yang menyebabkan rasa manis. Glikosida terdiri dari gula dan nongula (aglukon) (Ratnani dan Anggraeni, 2005). Madu merupakan komponen organik alami yang diproduksi dari nektar bunga melalui lebah. Madu memiliki rasa yang manis dan berbentuk cair. Madu mengandung gula, protein, mineral, vitamin, komponen aroma, dan polifenol (Arawwawala dan Hewageegana, 2017). Sorbitol memiliki tingkat kemanisan 0,6 jika dibandingkan sukrosa (Burnt, 2006).

Produk pangan termasuk minuman fungsional yang diproduksi harus memenuhi persyaratan keamanan, mutu, dan gizi pangan termasuk harus memenuhi persyaratan batas maksimum cemaran logam berat. Oleh karena itu, pada penelitian ini juga dilakukan pengukuran kandungan logam berat pada produk.

Tujuan dari penelitian ini yakni mengkarakterisasi sifat sensori dan kandungan logam berat minuman fungsional okra-jahe dengan penambahan berbagai jenis pemanis yaitu daun stevia, madu, sorbitol dan sukrosa.

\section{METODE PENELITIAN \\ Bahan dan Alat}

Bahan yang digunakan dalam penelitian ini adalah buah okra matang yang diperoleh dari Pasar Senen, sukrosa dari Pasar Pedok Tebet, madu dari minimarket daerah Pulogebang, sorbitol, daun stevia dari farmer future trader, jahe gajah dari Pasar Senen, air, $\mathrm{HNO}_{3}$ pa $65 \%, \mathrm{H}_{2} \mathrm{O}_{2}$ pa $30 \%$, dan $\mathrm{HClO}_{4}$ pa $70 \%$. Alat yang digunakan meliputi timbangan digital, gelas ukur, gelas piala, panci, kompor, blender, pisau, talenan, kain saring, instrumen Surface Area Analyzer (SAA) model NOVA-1000.

\section{Waktu \& Tempat Penelitian}

Penelitian dilakukan pada bulan JuliOktober 2018. Tempat penelitian dilakukan di laboratorium Pengolahan Pangan Fakultas Teknologi Pangan dan Kesehatan Universitas Sahid Jakarta, Laboratorium Kimia PT Soho; Laboratorium Vicomas; dan Laboratorium PT Mahakam Beta Farma.

\section{Tahapan Penelitian}

Penelitian terdiri dari tiga tahap. Tahap pertama adalah pembuatan formula produk minuman okra-jahe dengan penambahan 4 jenis pemanis yaitu sukrosa, sorbitol, madu, daun stevia. Tahap kedua adalah pengujian sifat kimia yang meliputi analisis logam berat $\mathrm{Pb}, \mathrm{Cd}, \mathrm{As}, \mathrm{Hg}$, dan Sn. Tahap ketiga adalah pengujian sifat sensoris dengan uji hedonik dengan parameter warna, rasa, aroma, dan viskositas.

\section{Pembuatan Formula (Modifikasi Azni et al., 2019)}

Buah okra disortasi, dibersihkan, dan dicuci dengan air bersih. Buah okra yang disortasi merupakan buah okra yang masih muda dengan kandungan lendir yang banyak. 
Kemudian dilakukan pengecilan ukuran dan diblansir pada suhu $80^{\circ} \mathrm{C}$ selama 5 menit. Setelah itu didinginkan dengan air es selama 5 menit dan ditiriskan. Buah okra dihancurkan dengan blender dan ditambahkan air dengan perbandingan 50:50. Bubur buah okra disaring dengan kain saring hingga dihasilkan sari buah okra.

Jahe disortasi, dibersihkan, dan dicuci dengan air bersih. Jahe dihancurkan menggunakan blender dan ditambahkan air dengan perbandingan 50:50. Bubur jahe kemudian disaring dengan kain saring sehingga dihasilkan ekstrak jahe. Perbandingan konsentrasi sari okra, jahe dan pemanis dalam formulasi minuman fungsional okra-jahe adalah 75:3:22.

Untuk membuat larutan stevia digunakan daun stevia kering dengan konsentrasi 3\% b/v. Daun stevia kering dilarutkan dalam air mendidih sambal diaduk selama 5 menit. Setelah itu disaring dan diambil filtratnya. Konsentrasi madu yang digunakan dalam larutan madu adalah $13.2 \% \mathrm{v} / \mathrm{v}$, sedangkan konsentrasi sukrosa dalam larutan sukrosa adalah $19.8 \%$ b/v. Sedangkan untuk jumlah sorbitol untuk larutan minuman okra-jahe $100 \mathrm{~mL}$ adalah sebanyak 33\% b/v. Diagram alir pembuatan minuman okra sebanyak 100 $\mathrm{mL}$ ) dapat dilihat pada Gambar 1. Penelitian dilakukan sebanyak tiga kali.

\section{Uji Organoleptik (Infantriani, 2016)}

Uji organoleptik terhadap daya terima makanan formula meliputi aspek warna, aroma, rasa, dan viskositas. Penilaian organoleptik ini dilakukan dengan menggunakan uji hedonik yang diukur berdasarkan tingkat kesukaan yaitu: $5=$ sangat suka, $4=$ suka, $3=$ agak suka, $2=$ tidak suka, 1 = sangat tidak suka. Dalam uji organoleptik dilibatkan 30 orang panelis semi terlatih. Panelis dipilih berdasarkan kriteria dalam keadaan sehat, tidak memiliki alergi terhadap bahan yang terdapat dalam formula, dan bersedia mengikuti uji organoleptik hingga selesai.

Pengujian Kadar Logam Berat (SNI 192896-1992)
Preparasi contoh menggunakan metode langsung yaitu contoh ditimbang sebayak 10 g lalu dimasukkan ke dalam piala gelas 100 mL. Contoh dipanaskan sampai alkohol atau gas $\mathrm{CO}_{2}$ dalam minuman tersebut menguap semua. Contoh dimasukkan ke dalam labu ukur $100 \mathrm{~mL}$, diencerkan, dan diimpitkan sampai tanda garis dengan air suling. Larutan contoh siap diukur kandungan logam berat ( $\mathrm{Hg}$, As, Cd, Pb dan $\mathrm{Sn}$ ) menggunakan Surface Area Analyzer (SAA) model NOVA-1000.

\section{HASIL DAN PEMBAHASAN Uji Organoleptik}

Hasil analisis organoleptik minuman fungsional okra-jahe pada penelitian ini dapat dilihat pada Tabel 1. Hasil tersebut menunjukkan bahwa minuman okra-jahe dengan penambahan pemanis sorbitol menghasilkan tingkat penerimaan terbaik oleh panelis jika ditinjau dari parameter warna (3.50) dan kekentalan (3.57), sedangkan dari parameter aroma dan warna, tingkat penerimaan terbaik ditunjukkan oleh minuman okra-jahe dengan pemanis sukrosa yaitu aroma 3.30 dan rasa 3.73.

Tabel 1 menunjukkan bahwa minuman okra-jahe dengan penambahan pemanis sorbitol menghasilkan tingkat penerimaan terbaik oleh panelis jika ditinjau dari parameter warna (3.5/cenderung suka) dan kekentalan (3.6/cenderung suka) sedangkan jika ditinjau dari parameter aroma dan warna, tingkat penerimaan terbaik terdapat pada minuman minuman okra-jahe dengan pemanis sukrosa yaitu aroma 3.3 (cenderung agak suka) dan rasa 3.7 (cenderung suka). Rasa banyak melibatkan panca indera lidah. Penginderaan cecapan dapat dibagi menjadi 4 cecapan utama yaitu asin, pedas, manis, dan asam. Rasa biasanya ditentukan oleh salah satu zat yang dominan yang bersifat mempengaruhi dalam susunan zat-zat yang memberikan rasa. Rasa sangat penting dalam mempengaruhi derajat penerimaan produk makanan atau minuman (Feriady, 2013). Tabel 1 menunjukkan bahwa penambahan pemanis sukrosa, sorbitol, dan madu mampu meningkatkan tingkat penerimaan konsumen terhadap rasa minuman okra-jahe jika dibandingkan dengan kontrol. 


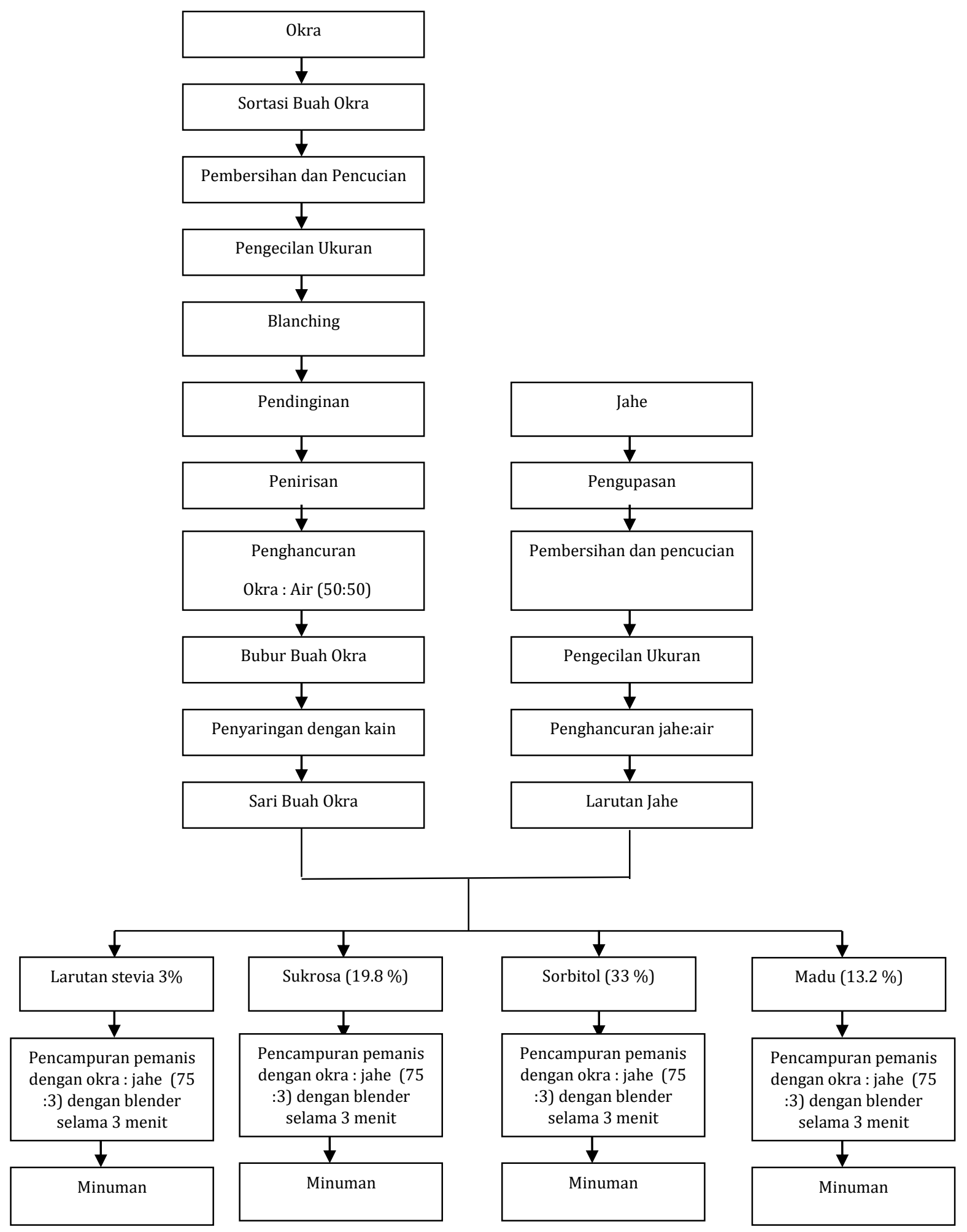

Gambar 1. Diagram Alir Pembuatan Minuman Fungsional Okra-Jahe(Formula $100 \mathrm{~mL}$ ) dengan Penambahan Berbagai Pemanis

Dari segi warna, produk yang ditambah pemanis daun stevia dan madu memiliki skor yang rendah. Hal ini disebabkan daun stevia yang digunakan pada penelitian ini adalah daun stevia yang kering. Pada daun stevia terdapat pigmen klorofil yang berubah menjadi cokelat akibat proses penjemuran di bawah sinar matahari (Hastuti dan Rustanti, 2014). Madu juga menghasilkan warna cokelat pada produk. Madu memiliki kandungan flavonoid yang tinggi. Flavonoid merupakan warna yang timbul khas 
berwarna coklat muda sampai coklat tua, flavonoid bersifat tahan terhadap pemanasan dan dapat larut dalam air. Warna cokelat dari produk membuat panelis kurang menyukainya. Berdasarkan parameter aroma diketahui bahwa minuman okra-jahe dengan penambahan daun stevia juga memiliki skor terendah hal ini disebabkan karena stevia menghasilkan aroma khas daun sehingga panelis tidak terlalu menyukainya.
Berdasarkan parameter viskositas minuman okra-jahe dengan penambahan pemanis sorbitol memiliki skor yang tinggi. Hal ini disebabkan formula tersebut memiliki jumlah komponen terlarut yang paling banyak dibanding formula lainnya sehingga terasa lebih kental. Menurut Bourne (1982) , komponen terlarut yang semakin besar dalam suatu larutan akan meningkatkan nilai viskositas/kekentalannya.

Tabel 1. Hasil Uji Hedonik Minuman Okra-Jahe dengan Penambahan Berbagai Pemanis

\begin{tabular}{cccccc}
\hline Parameter & Sukrosa & Sorbitol & Madu & Daun Stevia & Kontrol \\
\hline Warna & 3.4 & 3.5 & 2.3 & 2.6 & 3.3 \\
Aroma & 3.3 & 3.3 & 2.8 & 2.4 & 2.8 \\
Rasa & 3.7 & 3.6 & 2.8 & 2.0 & 2.1 \\
Viskositas & 3.4 & 3.6 & 3.1 & 3.1 & 3.2 \\
\hline
\end{tabular}

Ket.: $1=$ Sangat tidak suka; 2 = tidak suka; 3 = Agak suka; 4 = Suka; 5 = Sangat suka

Penelitian penambahan jahe dalan minuman fungsional juga telah dilakukan oleh beberapa penelitian, salah satunya dilakukan pada produk minuman fungsional berbasis kumis kucing. Hasil penelitian menunjukkan bahwa skor kesukaan panelis terhadap citarasa minuman formula optimal (skor hedonik 3.32 dari skala 5.00) tidak dapat dibedakan secara nyata dibandingkan skor kesukaan panelis terhadap citarasa beberapa produk minuman komersil pada taraf signifikansi 5\%. Panelis lebih menyukai ( $\alpha=0.05$ ) warna minuman formula optimal (skala hedonik 3.48 dari skala 5.00), dibandingkan warna minuman komersil berbasis jahe (skor hedonik 2.84 dari skala 5.00), (Herold, 2007).

Penelitian penambahan bahan pemanis pada minuman fungsional juga telah banyak dilakukan, salah satunya pada minuman fungsional yoghurt. Penambahan ekstrak kayu secang dan esktrak daun stevia dalam yoghurt dapat meningkatkan aktivitas antioksidan produk dan kesukaan panelis terhadap produk baik 16 dari sisi warna, aroma maupun rasa. Penambahan esktrak daun stevia dalam yoghurt meningkatkan kadar gula total yoghurt karena ekstrak daun stevia memiliki kadar gula yang dapat meningkatkan kadar gula total, sehingga dapat meningkatkan kesukaan panelis terhadap produk (Umami, 2015).

Bahan pemanis lain yang biasanya ditambahkan yakni madu. Salah satu penelitian tentang hal tersebut, yakni penambahan berbagai jenis madu sebagai alternatif pemanis minuman sari buah naga putih. Hasil penelitian menunjukkan bahwa terdapat perbedaan penerimaan panelis pada masing-masing perlakuan. penilaian penelis terhadap warna sari buah naga paling tinggi ditunjukkan pada sampel sari buah naga dengan penambahan madu kelengkeng 10\%, karena warna yang dihasilkan berwarna cokelat muda, sehingga membuat panelis lebih tertarik berdasakan warna yang dihasilkan apabila dibandingkan dengan kontrol yang berwarna putih. Adapun penilaian panelis terhadap warna sari buah naga paling rendah ditunjukkan pada sampel dengan penambahan madu randu $15 \%$, karena produk yang dihasilkan berwarna cokelat tua atau lebih hitam, sehingga panelis kurang menyukainya. Hasil penelitian juga 
menunjukkan bahwa penilaian penelis terhadap rasa sari buah naga paling tinggi ditunjukkan pada sampel sari buah naga dengan penambahan madu kelengkeng 10\% karena rasa yang dihasilkan manis dan tidak hambar. Adapun untuk penilaian panelis terhadap rasa sari buah naga paling rendah ditunjukkan pada sampel dengan penambahan madu randu $15 \%$ karena rasa yang dihasilkan agak pahit, sehingga panelis kurang menyukainya (Aji et al., 2013).

\section{Logam Berat}

Setiap produk pangan baik berupa makanan dan minuman yang diproduksi dan akan diedarkan harus memenuhi persyaratan keamanan, mutu, dan gizi, termasuk persyaratan batas maksimum cemaran logam berat. Tabel 2 menunjukkan kandungan logam berat minuman fungsional okra-jahe dengan penambahan berbagai jenis pemanis. Tabel 2 menunjukkan bahwa semua minuman okra-jahe dengan berbagai jenis pemanis telah memenuhi persyaratan SNI 01-3719-1995 (standar mutu minuman sari buah).

Logam berat yang dipersyaratkan memiliki batas maksimum pada umumnya berupa timbal $(\mathrm{Pb})$, Cadmium $(\mathrm{Cd})$, Arsen (As), Merkuri (Hg), dan Timah (Sn). Timbal $(\mathrm{Pb})$ merupakan logam yang sangat beracun. Konsumsi timbal dalam jumlah banyak secara langsung dapat menyebabkan kerusakan jaringan serta dapat merusak syaraf. Arsen (As) merupakan elemen paling toksik dan apabila tertelan dapat menyebabkan penurunan produksi sel darah merah dan sel darah putih. Konsentrasi 0.010 $\mathrm{mg} / \mathrm{L}$ dalam air minum dapat menyebabkan kerusakan kulit dan system sirkulasi serta dapat meningkatkan resiko kanker. Kadmium (Cd) merupakan senyawa yang bersifat karsinogen yang dapat merusak pencernaan, paru-paru dan ginjal. Merkuri (Hg) merupakan salah satu logam berat yang berbahaya yang dapat memengaruhi otak dan fungsi lainnya, dan akan menyebabkan bermacam-macam gejala seperti mudah marah, suka gemetar, kehilangan sensasi, kesulitas daya ingat, dan otak yang tidak teroganisir dengan baik. Timah (Sn) merupakan unsur logam yang berwarna keperakan. Konsumsi timah dalam pangan yang berlebihan dapat menyebabkan iritasi saluran pencernaan yang ditandai dengan gejala muntah, diare, kelelahan, dan sakit kepala. Pada dosis akut dapat menyebabkan anoreksia, ataksia, kelemahan otot, serta pembengkakan usus halus, hingga kematian (SNI 7387:2009).

Pengukuran logam berat pada minuman fungsional juga dilakukan oleh beberapa penelitian lain. Hasil penelitian Anggraini (2014), menunjukkan bahwa minuman fungsional sawo dan kayu manis dinyatakan tidak mengandung logam $\mathrm{Pb}$, tetapi mengandung logam $\mathrm{Zn}$ sebesar $0.95 \mathrm{mg} / \mathrm{L}$ dan logam Cu sebesar $0.285 \mathrm{mg} / \mathrm{L}$.

Tabel 2. Kandungan Logam Berat Minuman Fungsional Okra-Jahe dengan Berbagai Jenis Pemanis

\begin{tabular}{ccccccc}
\hline $\begin{array}{c}\text { Logam } \\
\text { Berat }\end{array}$ & Sukrosa & Sorbitol & Madu & Daun Stevia & Kontrol & SNI 01-3719-1995 \\
\hline $\mathrm{Pb}$ & Negatif & Negatif & Negatif & Negatif & Negatif & Maks. 0.3 mg/kg \\
$\mathrm{Cd}$ & Negatif & Negatif & Negatif & Negatif & Negatif & - \\
$\mathrm{As}$ & Negatif & Negatif & Negatif & Negatif & Negatif & Maks. 0,2 mg/kg \\
$\mathrm{Hg}$ & Negatif & Negatif & Negatif & Negatif & Negatif & Maks. 0.03 mg/kg \\
$\mathrm{Sn}$ & Negatif & Negatif & Negatif & Negatif & Negatif & Maks. $40 \mathrm{mg} / \mathrm{kg}$ \\
\hline
\end{tabular}

\section{KESIMPULAN}

Berdasarkan uji hedonik, untuk parameter warna dan kekentalan minuman okra dengan pemanis sorbitol mendapatkan skor yang tertinggi. Sedangkan pada parameter rasa dan aroma yang mendapatkan skor yang 
tertinggi adalah minuman okra dengan pemanis sukrosa. Hasil uji logam berat $\mathrm{Pb}, \mathrm{Cd}$, As, $\mathrm{Hg}$, dan Sn menunjukkan bahwa minuman fungsional okra-jahe dengan kelima jenis pemanis yang dicobakan memenuhi persyaratan SNI 01-3719-1995 (standar mutu minuman sari buah).

\section{UCAPAN TERIMA KASIH}

Terima kasih kepada Kementerian Riset dan Teknologi Direktorat Jenderal Pendidikan Tinggi yang telah membiayai penelitian ini melalui Penelitian Dosen Pemula Tahun Anggaran 2018 dengan nomor surat perjanjian 69.04/USJ-11/H.56/2018.

\section{DAFTAR PUSTAKA}

Aji, S.P., Katri, R.B., \& Nurhartadi, E., 2013. Penambahan berbagai jenis madu sebagai alternatif pemanis minuman sari buah naga putih (Hylocereus undatus). Biofarmasi, 11(1), pp. 13-18 ISSN: 16932242.

Anggraini, F.N., 2014. Aktifitas Antioksidan dan Mutu Sensori Formulasi Minuman Fungsional Sawo dan Kayu Manis. Universitas Islam Negeri Syarif Hidayatullah, Jakarta.

Arawwawala, L.D.A.M. \& Hewageegana, H.G.S.P., 2017. Health benefits and traditional uses of honey: a review. J. Apither, 2(1), pp. 9-14.

Azni, I.N., Amelia, J.R., Andriantini, A., Rismawati, A., 2019. Karakteristik kimia minuman okra dengan penambahan daun stevia dan ekstrak jahe. Jurnal Agroindustri Halal, 5(1), hal. 1-8.

Bourne, L., 1982. Typicality effects in logically defined categories. Memory \& Cognition, 10 , pp. 3-9.

Burnt, B.A., 2006. The use of sorbitol- and xylitol-sweetened chewing gum in caries control. JADA, 137, pp.190-6.

Feriady, A., 2013. Pengaruh metode pengeringan terhadap tingkat kesukaan teh buah rosela (Hibiscus sabdarifa L.). Agribis, IV(1)
Gemede, H.F., Ratta, N., Haki, G.D., Woldegiorgis, A.Z., \& Beyene, F., 2015. Nutritional quality and health benefits of okra (abelmoschus esculentus): a review. Food Science and Quality Management, 6(6), pp. 1-6.

Gupta, S.K., \& Sharma A., 2014. Medicinal properties of Zingiber officinale Roscoe - a review. OSR-JPBS, 9(5), pp. 124-9.

Hastuti, A.M., \& Rustanti, N., 2014. Pengaruh Penambahan Kayu Manis Terhadap Aktivitas Antioksidan dan Kadar Gula Total Minuman Fungsional Secang dan Daun Stevia Sebagai Alternatif Minuman Bagi Penderita Diabetes Melitus Tipe 2. Journal of Nutrition College, 3(3), pp. 3629.

Herold, 2007. formulasi minuman fungsional berbasis kumis kucing (Orthosiphon aristatus bl. miq) yang didasarkan pada optimasi aktivitas antioksidan, mutu citarasa dan warna. Institut Pertanian Bogor, Bogor.

Infantriani, A.S, 2016. Pengembangan bahan makanan campuran berbasis tepung kacang hijau dengan nilai mutu protein yang tinggi untuk balita gizi kurang. Fakultas Kesehatan Universitas $\mathrm{MH}$ Thamrin Jakarta.

Ratnani, R.D., \& Anggraeni, R., 2005. Ekstraksi gula stevia dari tanaman stevia rebaudiana bertoni. Momentum, 1(2), pp. 7-32.

Standar Nasional Indonesia, 1995. Minuman Sari Buah. Badan Standardisasi Nasional.

Standar Nasional Indonesia (SNI 7387:2009), 2009. Batas Maksimum Cemaran Logam Berat dalam Pangan. Badan Standardisasi Nasional.

Umami, C., 2015. Pengaruh penambahan ekstrak kayu secang dan ekstrak daun stevia terhadap aktivitas antioksidan dan kadar gula total pada yoghurt sebagai alternatif minuman bagi penderita diabetes melitus tipe 2. Program Studi Ilmu Gizi Fakultas Kedokteran Universitas Diponegoro, Semarang. 


\section{BIODATA}

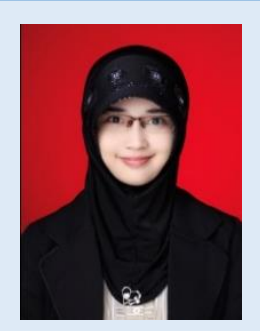

Dr. Julfi Restu Amelia, STP, MSi, dilahirkan pada 27 Februari 1989. Pada tahun 2010 menyelesaikan studi pada program studi Teknologi Hasil Pertanian Universitas Lampung. Pada tahun 2012 menyelesaikan studi pada program magister Teknologi Hasil Pertanian Universitas Lampung. Pada tahun 2017 menyelesaikan studi pada program Doktoral Teknologi Industri Pertanian IPB. Saat ini sebagai staf pengajar Universitas Sahid Jakarta pada program studi Teknologi Pangan

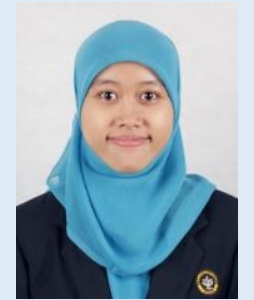

Intan Nurul Azni, SKM, MSi, dilahirkan pada 4 Januari 1988. Pada tahun 2009 menyelesaikan studi pada program studi Gizi Kesehatan Masyarakat Universitas Indonesia. Pada tahun 2013 menyelesaikan studi pada program magister Ilmu Pangan IPB. Saat ini sebagai staf pengajar Universitas Sahid Jakarta pada program studi Teknologi Pangan

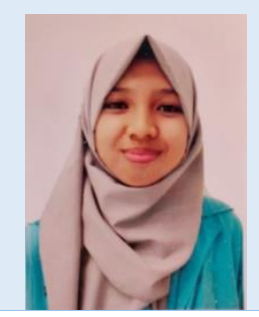

Rusi Dwi Oktaviani dilahirkan pada 15 Oktober 1996 saat ini bekerja di PT Soho Industri Pharmasi sebagai analis kimia pada bagian research and development dan sedang menjalani studi SI di Universitas Sahid Jakarta dengan program studi teknologi pangan. 